\title{
Indices of Metabolic Dysfunction and Oxidative Stress
}

\author{
Gemma Casadesus · Paula I. Moreira - Akihiko Nunomura $\cdot$ Sandra L. Siedlak · \\ William Bligh-Glover · Elizabeth Balraj · Grace Petot · Mark A. Smith · \\ George Perry
}

Accepted: 18 September 2006/Published online: 7 March 2007

(C) Springer Science+Business Media, LLC 2007

\begin{abstract}
Metabolic alterations are a key player involved in the onset of Alzheimer disease pathophysiology and, in this review, we focus on diet, metabolic rate, and neuronal size differences that have all been
\end{abstract}

Special issue dedicated to John P. Blass.

Gemma Casadesus and Paula I. Moreira contributed equally to this paper. Aspects of this paper were previously presented in Neurochemical Research 28, 1549-1552, 2003 and the Journal of Alzheimer's Disease 1, 203-206, 1999 and were used here with permission.

\section{G. Casadesus}

Department of Neuroscience, Case Western Reserve

University, Cleveland, $\mathrm{OH}$, USA

\section{P. I. Moreira}

Center for Neuroscience and Cell Biology of Coimbra, University of Coimbra, Coimbra, Portugal

\section{A. Nunomura}

Department of Psychiatry and Neurology, Asahikawa

Medical College, Asahikawa, Japan

S. L. Siedlak · M. A. Smith · G. Perry

Department of Pathology, Case Western Reserve

University, Cleveland, OH, USA

W. Bligh-Glover · E. Balraj

Cuyahoga County Coroner's Office, 11001 Cedar Avenue,

Cleveland, $\mathrm{OH}$, USA

G. Petot

Department of Nutrition, Case Western Reserve University, Cleveland, OH, USA

\section{G. Perry ( $\square)$}

College of Sciences, University of Texas at San Antonio, 6900 North Loop 1604 West, San Antonio, TX 78249-0661, USA

e-mail: george.perry@utsa.edu shown to play etiological and pathological roles in Alzheimer disease. Specifically, one of the earliest manifestations of brain metabolic depression in these patients is a sustained high caloric intake meaning that general diet is an important factor to take in account. Moreover, atrophy in the vasculature and a reduced glucose transporter activity for the vessels is also a common feature in Alzheimer disease. Finally, the overall size of neurons is larger in cases of Alzheimer disease than that of age-matched controls and, in individuals with Alzheimer disease, neuronal size inversely correlates with disease duration and positively associates with oxidative stress. Overall, clarifying cellular and molecular manifestations involved in metabolic alterations may contribute to a better understanding of early Alzheimer disease pathophysiology.

Keywords Alzheimer disease - Apolipoprotein E . Diet $\cdot$ Metabolism $\cdot$ Neuronal size

\section{Brief introduction}

There are a great number of hypotheses concerning Alzheimer disease (AD). The predominant theories focus on specific abnormalities that are used in the diagnosis of disease such as production of amyloid- $\beta$ $\left(\mathrm{A} \beta_{42}\right)[1-3]$ and $\tau$ phosphorylation $[4,5]$. As previously discussed [6-8], the lesions of disease should be viewed as surrogates or consequences of the disease process rather than pathogenic. With this in mind, we previously found that oxidative stress precedes both pathologies by decades in both sporadic and familial AD [9-14]. Key factors contributing to oxidative stress in $\mathrm{AD}$ are slowly being elucidated with redox metal 
ions [15, 16], mitochondria [17], and mitotic alterations being the focus of our groups. Bringing all these aspects together, this review explores the interplay between metabolic factors, which have been implicated in the progression and pathogenesis of $\mathrm{AD}$.

\section{Brain metabolism in Alzheimer disease}

John Blass and colleagues presented some of the earliest, and many would say best, biochemical studies of AD highlighting deficiencies in key enzymes of energy metabolism, in particular $\alpha$-ketoglutarate and pyruvate dehydrogenase [18-20]. Reduced enzymatic activities were not only noted in brain of AD cases but also in other tissues and even in fibroblasts cultured from AD patients. Consistent with this, metabolic imaging studies show reduced glucose utilization as early as, maybe even preceding, the onset of clinical symptoms, in genetically predisposed individuals [21]. Indeed, reduced glucose metabolic rate in the temporoparietal and posterior cingulate cortex is evident in both $\mathrm{AD}$ and in subjects with mild cognitive impairment (MCI) [22]. That such metabolic alterations are key contributors to the pathogenesis of $\mathrm{AD}$ is highlighted by studies on patients with at least one $\varepsilon 4$ allele of apolipoprotein E (ApoE), where reduced glucose metabolism levels in limbic and associative areas of the brain supports the notion that ApoE4 carriers are more prone to develop metabolic deficiency and $\mathrm{AD}$ at an early age [23]. Moreover, such changes are evident even in young and presymptomatic ApoE4 carriers [24], indicating a possible causal route of AD in ApoE4 individuals.

The vasculature, the major metabolic exchange surface of the brain, is consistently atrophied in AD [25] and, like other brain compartments, shows reduced glucose transport [26]. These findings emphasize the multiplicity of causes and effects of lowered metabolic function such that baseline glucose metabolism and medial temporal lobe brain volumes are predictive of cognitive decline in normal older people [27]. Notably, amyloid- $\beta$ interacts with insulin receptors and glucose transporters [28] and there are emerging parallels being drawn between diabetes and AD [29-32]. Indeed, amyloid formation in the pancreas is associated with $\beta$-cell loss in Type 2 diabetes [33] and a disturbance in the control of neuronal glucose metabolism, consequent to impaired insulin signaling atrophy, resembles the pathophysiology of Type- 2 diabetes in non-neuronal tissue [34]. Seen together, these findings make a case for a metabolic contribution to the pathogenesis of $\mathrm{AD}$.

\section{Dietary intake and Alzheimer disease}

The cerebral metabolic alterations in AD patients mentioned above are likely reflective or consequential to a number of factors including dietary intake. In this regard, a high caloric diet seemingly predates onset of disease [35-37] (Table 1). Moreover, patients who later develop AD show reduced intake of key antioxidant nutrients throughout life (Table 2).

Lipid transport is a known function of apolipoprotein $\mathrm{E}$ (ApoE), whose genotype has been established as a risk factor for AD [38]. Proper functioning of this protein is critical to membrane formation and the repair of nervous system injuries. Notably, a high fat diet is a risk factor in the development of $\operatorname{AD}[39,40]$.

Table 1 Caloric intake of $\mathrm{AD}$ and control cases during three periods of adult life, ages 20-39 years, 40-59 years and 60+ years

\begin{tabular}{llll}
\hline Age Period & Mean & Median & S.D. \\
\hline 20`S and 30‘S & & & \\
AD $(n=78)$ & 2115 & 2051 & 715 \\
Controls $(n=212)$ & 2092 & 2100 & 641 \\
$40 ` S$ and 50‘S & & & \\
AD $(n=108)$ & 2152 & 2089 & 710 \\
Controls $(n=225)$ & 2076 & 2125 & 648 \\
60+ & & & \\
AD $(n=84)$ & 2148 & 2076 & 702 \\
Controls $(n=232)$ & 1704 & 1658 & 487 \\
\hline
\end{tabular}

Reprinted from J Alzheimer's Disease 1:203-206, 1999 with permission from IOS Press

Table 2 Dietary patterns throughout life indicate significantly greater consumption by controls than $\mathrm{AD}$ cases of vitamins $\mathrm{A}, \mathrm{C}$ and carotenoids, and more servings per day of foods that contain these nutrients (37)

\begin{tabular}{llll}
\hline $\begin{array}{l}\text { Nutrients per 1000 } \\
\text { kilocalories }\end{array}$ & $\begin{array}{l}\text { AD } \\
\text { Cases } \\
n=104\end{array}$ & $\begin{array}{l}\text { Controls } \\
n=223\end{array}$ & $P$ Value \\
\hline Vitamin A (RE) & 855 & 983 & .001 \\
$\alpha$ Carotene (mcg) & 294 & 389 & $<.001$ \\
$\beta$ Carotene (mcg) & 1921 & 2370 & .003 \\
Pro-ACarotene (mcg) & 2231 & 2809 & .001 \\
Lutein (mcg) & 972 & 1214 & .015 \\
Lycopene (mcg) & 666 & 927 & $<.001$ \\
Vitamin C (mg) & 74.6 & 86.7 & .007 \\
Vitamin E ( $\alpha$ TE) & 5.6 & 5.9 & $\mathrm{NS}$ \\
Servings per day & & & .022 \\
Yollow green vegetables & 2.0 & 2.3 & $\mathrm{NS}$ \\
Vitamin C fruit, & 2.4 & 2.6 & \\
$\quad$ vegetables & & &
\end{tabular}

These data strongly support the notion that free radical scavengers, here dietary antioxidants, delay or prevent the onset of AD. Reprinted from J Alzheimer's Disease 1:203-206, 1999 with permission from IOS Press 
Interestingly, diet can also influence pathological markers of $\mathrm{AD}$. In this regard, and associated with insulin function/resistance and metabolism, recent data indicates that Insulin-degrading enzyme (IDE), one protein with a key role in degrading amyloid- $\beta$ monomer [41], is decreased in AD [42]. Providing interplay between the aforementioned high fat diets contribute to insulin resistance and lower IDE and, in animal models of $\mathrm{AD}$, lead to increased amyloid deposition [43]. Altogether, these data indicate a key role that dietary influences may play in maintaining healthy brain structure and function.

\section{Neuronal size and Alzheimer disease}

To clarify the relationship between brain metabolic activity, neuronal size, and the evolution of $\mathrm{AD}$, we found, in a study of oxidative damage in $\mathrm{AD}$ and normal aging, a strong inverse relationship between neuronal oxidative damage (8-hydroxyguanosine, a marker of nucleic acid oxidation) and neuronal size among cases of AD but not controls (Fig. 1). Additionally, we showed that, in AD cases, neuronal size is inversely correlated with the duration of the disease (Fig. 2). Previous studies found that during the progression of the disease there is a significant decrease in the size of neurons in AD when compared to controls [12, 35] and our data (Fig. 2) would tend to support this. However, while the differences in neuron size are highly correlated with oxidative damage and duration of disease among the $\mathrm{AD}$ cases, the increase in size is not statistically different from control cases. An alternative and more provocative possibility for this discrepancy could be explained by an antioxidant role of

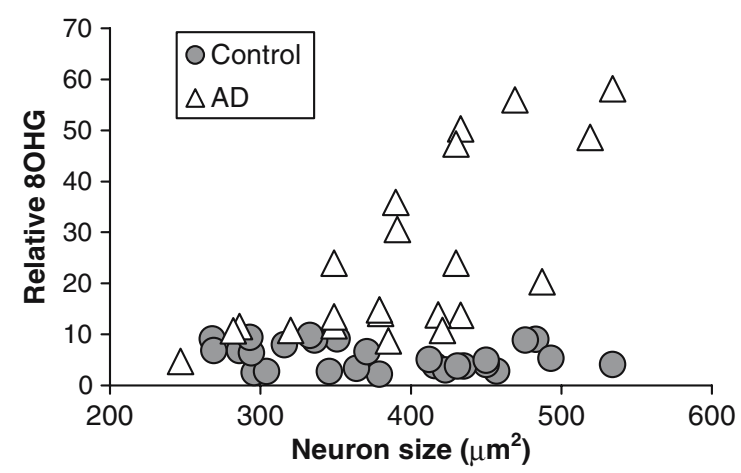

Fig. 1 In cases of $\mathrm{AD}$, neuron size is directly correlated with increased levels of 8-hydroxyguanosine (8OHG) $(P=0.002)$, while control cases do not display this relationship $(P=0.18)$. Reprinted from Neurochem Res 28:1549-1552, 2003 with kind permission of Springer Science and Business Media

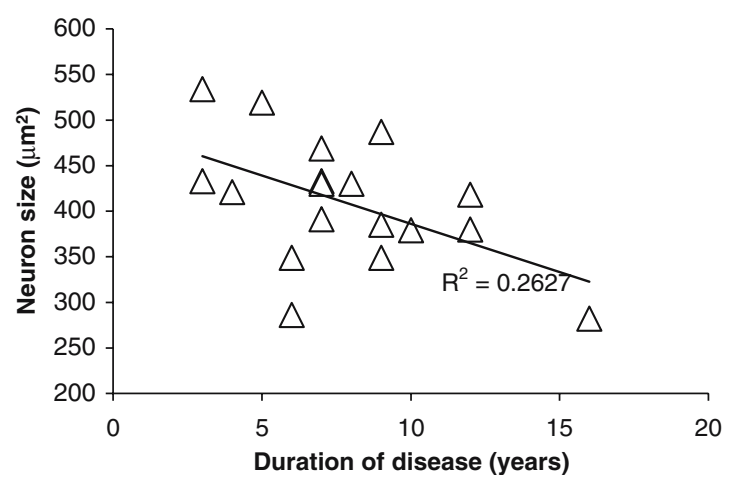

Fig. 2 In cases of $A D$, neuron size is inversely correlated with the duration of the disease $(P=0.03)$. This buttresses our previous finding that neuron size decreases with increasing levels of amyloid. Reprinted from Neurochem Res 28:1549-1552, 2003 with kind permission of Springer Science and Business Media

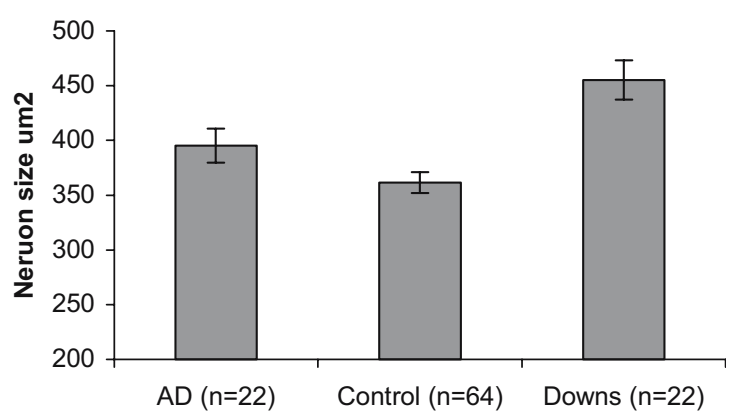

Fig. 3 Neuron size was measured in the same area of the hippocampus in $\operatorname{AD}(n=22)$, Down syndrome $(n=22)$ and control $(n=64)$ cases. Cases of Down syndrome had significantly larger neurons than the control cases $(P=0.00006)$. While the average neuron size for the AD cases was higher than the control cases, the difference did not reach significance $(P=0.076$; Student's t-test). Reprinted from Neurochem Res 28:1549-1552, 2003 with kind permission of Springer Science and Business Media

amyloid- $\beta$ [8]. Given that amyloid- $\beta$ can serve an antioxidant function, one possibility could be that amyloid- $\beta$ appears as a protective mechanism in a brain inherently vulnerable to oxidative stress, which initially normalizes neuronal function and size and then through progressive accumulation alters cellular structures enough to cause neuronal shrinkage and death, as other reports have shown [6-14]. Nonetheless, it is intriguing that large neurons in AD appear most vulnerable and supporting this, we also observed that neurons from cases of Down syndrome are significantly larger than control cases (Fig. 3). Down syndrome parallels AD in lesion formation, markers of oxidative damage and most of the other changes of $\mathrm{AD}$, yet these changes occur decades earlier [44]. In 
Table 3 Comparison of previous population studies of $A p o E$ allele frequencies and the cases used in this study

\begin{tabular}{|c|c|c|c|c|c|}
\hline Diagnosis & ApoE2 (\%) & ApoE4 (\%) & Ratio $E 4 / E 2$ & Age & $n$ \\
\hline Control [53] & 7.8 & 16.9 & 2.17 & 76 & 71 \\
\hline Dementia [53] & 2.8 & 22.2 & 7.9 & 80 & 18 \\
\hline Psychiatric history [53] & 12.5 & 10.7 & 0.85 & 71.8 & 28 \\
\hline Control (Caucasian) [54] & 7 & 12.5 & 1.79 & $<30$ & 939 \\
\hline Control (African-American) [54] & 14 & 20 & 1.43 & $<30$ & 696 \\
\hline Psychotic (Bipolar) [52] & 6.3 & 15.1 & 2.39 & Mean 33-67 & 156 \\
\hline Control [52] & 6 & 12.1 & 2.0 & Mean 43.5 & 91 \\
\hline Schizophrenic [55] & 7 & 7.5 & 1.07 & $12-87$ & 54 \\
\hline Dementia [55] & 4.6 & 30.2 & 6.6 & $50-95$ & 43 \\
\hline Control [55] & 6 & 15.2 & 2.5 & $24-88$ & 33 \\
\hline Control [56] & 3.7 & 19.5 & 5.7 & $<18$ & 486 \\
\hline Post-mortem Control $^{\mathrm{a}}$ & 23 & 11.5 & 0.5 & $<40$ & 13 \\
\hline 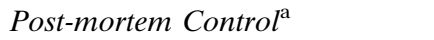 & 0 & 12.5 & & $>40$ & 8 \\
\hline
\end{tabular}

a Cases obtained from the Cuyahoga County Coroner Office, Cleveland, Ohio

As expected, the populations with dementia display the highest frequency of $\varepsilon \mathrm{E} 4$ and the highest ratio of $\varepsilon \mathrm{E} 4 / \mathrm{E} 2,6.6$ and 7.9 . The 6 control populations, not including our data, have a E4/E2 ratio from 1.43-5.7, with the average frequency of E4 being about 2.5 times greater than E2. Interestingly, in 2 of the 3 previous studies of ApoE genotype and psychotic behavior, the ratio of E4/E2 is 1.07 and 0.85. Our population study displayed an even greater frequency of ApoE2. Of the 6 cases carrying the ApoE2 allele, 3 committed suicide. In other words, ApoE2 may be a risk factor for mental illness

addition, Down syndrome cases also experience neuronal loss and have similar genetic risk factors [35].

To determine the relationship between neuronal size, $\mathrm{AD}$, and $A p o E$ genotype, we determined the $A p o E$ genotype of the control cases to identify those at risk of AD. Control cases (ages $42-85$ years) with at least one ApoE4 allele had a cross sectional area significantly larger compared to other controls lacking ApoE4. In contrast, young controls (ages 20-40 years) show no correlation between neuronal size and $A p o E$ genotype. These findings further suggest that the ApoE4 allele may play a role during aging and disease progression that influences neuron size. As such, one possibility is that the alteration of lipid or axonal transport of ApoE4 carriers may be a cause of the accumulation of organelles [45] within neurons early in the disease, leading to a neuronal enlargement and then to neuronal shrinkage and death during the progression of AD. Supporting this idea, while AD is associated with a significantly reduced size of the Golgi apparatus, individuals with mild cognitive impairment (MCI) show substantially increased size [46]. Another possibility is that, in order to compensate for metabolic dysfunction produced by, for example, ApoE4 status, organelles associated with metabolism undergo a compensatory enlargement that may then lead to further damage and subsequent shrinkage and death of the neuron in more advanced stages of AD.

As a side note, related to ApoE genotype, an interesting trend was apparent when analyzing young controls. Out of 13 cases under the age of 32, six carried an ApoE2 allele. Most of the genetic studies in aging and AD focus on the increase in ApoE4 [47] and some studies [48-50], but not all [51], have noted that ApoE2 is protective for AD. We compared our relatively small sample population with published studies and determined that the frequency of ApoE2 was much higher than those reported for other control populations (Table 3). Of note was the fact that our samples were obtained postmortem and of the 6 cases carrying an ApoE2 allele, 3 committed suicide and 2 succumbed to violence. In previous studies, the frequency of ApoE2 was increased in cases with psychosis $[24,52]$. Our results fall into this category-perhaps, ApoE2 genotype is a determinant of susceptibility to violent death.

\section{Conclusion}

While the data presented above do not illustrate a causal relationship between neuronal size and $A D$ development and progression, these changes occur due to metabolic alterations that appear early in the onset of the disease. Although there is insufficient data to know if diet can be protective for neurodegeneration, or, instead, is a surrogate marker of other lifestyle patterns promoting general health, it is well known that proper nutrition and a healthy diet are essential for maintaining overall good health and, therefore, can be beneficial to $\mathrm{AD}$ patients. These findings allow the development of new studies focused on the events associated with the onset of the disease process such as diet, glucose metabolism, and neuronal size. Those 
studies could be critical for the understanding of basic mechanisms underlying $\mathrm{AD}$ pathophysiology and, consequently, the development of new therapeutic strategies.

Acknowledgments This research was supported by the National Institutes of Health, Alzheimer's Association, and Philip Morris Inc. USA and Philip Morris International.

\section{References}

1. Hardy J, Selkoe DJ (2002) The amyloid hypothesis of Alzheimer's disease: progress and problems on the road to therapeutics. Science 297:353-356

2. Hardy JA, Higgins GA (1992) Alzheimer's disease: the amyloid cascade hypothesis. Science 256:184-185

3. Selkoe DJ (2001) Alzheimer's disease results from the cerebral accumulation and cytotoxicity of amyloid betaprotein. J Alzheimers Dis 3:75-80

4. Trojanowski JQ, Clark CM, Arai H, Lee VM (1999) Elevated levels of tau in cerebrospinal fluid: implications for the antemortem diagnosis of Alzheimer's disease. J Alzheimers Dis 1:297-305

5. Gomez-Ramos A, Smith MA, Perry G, Avila J (2004) Tau phosphorylation and assembly. Acta Neurobiol Exp (Wars) 64:33-39

6. Castellani RJ, Lee HG, Zhu X, Nunomura A, Perry G, Smith MA (2006) Neuropathology of Alzheimer disease: pathognomonic but not pathogenic. Acta Neuropathol (Berl) 111:503-509

7. Lee HG, Perry G, Moreira PI, Garrett MR, Liu Q, Zhu X, Takeda A, Nunomura A, Smith MA (2005) Tau phosphorylation in Alzheimer's disease: pathogen or protector? Trends Mol Med 11:164-169

8. Smith MA, Casadesus G, Joseph JA, Perry G (2002) Amyloid-beta and tau serve antioxidant functions in the aging and Alzheimer brain. Free Radic Biol Med 33:1194-1199

9. Perry G, Castellani RJ, Hirai K, Smith MA (1998) Reactive oxygen species mediate cellular damage in Alzheimer disease. J Alzheimers Dis 1:45-55

10. Zhu X, Raina AK, Perry G, Smith MA (2004) Alzheimer's disease: the two-hit hypothesis. Lancet Neurol 3:219-226

11. Nunomura A, Chiba S, Lippa CF, Cras P, Kalaria RN, Takeda A, Honda K, Smith MA, Perry G (2004) Neuronal RNA oxidation is a prominent feature of familial Alzheimer's disease. Neurobiol Dis 17:108-113

12. Nunomura A, Perry G, Aliev G, Hirai K, Takeda A, Balraj EK, Jones PK, Ghanbari H, Wataya T, Shimohama S, Chiba S, Atwood CS, Petersen RB, Smith MA (2001) Oxidative damage is the earliest event in Alzheimer disease. J Neuropathol Exp Neurol 60:759-767

13. Nunomura A, Perry G, Pappolla MA, Friedland RP, Hirai K, Chiba S, Smith MA (2000) Neuronal oxidative stress precedes amyloid-beta deposition in Down syndrome. $\mathbf{J}$ Neuropathol Exp Neurol 59:1011-1017

14. Nunomura A, Perry G, Pappolla MA, Wade R, Hirai K, Chiba S, Smith MA (1999) RNA oxidation is a prominent feature of vulnerable neurons in Alzheimer's disease. J Neurosci 19:1959-1964

15. Smith MA, Harris PL, Sayre LM, Perry G (1997) Iron accumulation in Alzheimer disease is a source of redoxgenerated free radicals. Proc Natl Acad Sci USA 94:98669868
16. Sayre LM, Perry G, Harris PL, Liu Y, Schubert KA, Smith MA (2000) In situ oxidative catalysis by neurofibrillary tangles and senile plaques in Alzheimer's disease: a central role for bound transition metals. J Neurochem 74:270-279

17. Hirai K, Aliev G, Nunomura A, Fujioka H, Russell RL, Atwood CS, Johnson AB, Kress Y, Vinters HV, Tabaton M, Shimohama S, Cash AD, Siedlak SL, Harris PL, Jones PK, Petersen RB, Perry G, Smith MA (2001) Mitochondrial abnormalities in Alzheimer's disease. J Neurosci 21:30173023

18. Blass JP, Sheu RK, Gibson GE (2000) Inherent abnormalities in energy metabolism in Alzheimer disease. Interaction with cerebrovascular compromise. Ann N Y Acad Sci 903:204-221

19. Sheu KF, Cooper AJ, Koike K, Koike M, Lindsay JG, Blass JP (1994) Abnormality of the alpha-ketoglutarate dehydrogenase complex in fibroblasts from familial Alzheimer's disease. Ann Neurol 35:312-318

20. Hoshi M, Takashima A, Noguchi K, Murayama M, Sato M, Kondo S, Saitoh Y, Ishiguro K, Hoshino T, Imahori K (1996) Regulation of mitochondrial pyruvate dehydrogenase activity by tau protein kinase I/glycogen synthase kinase 3beta in brain. Proc Natl Acad Sci USA 93:2719-2723

21. Small GW (1996) Neuroimaging and genetic assessment for early diagnosis of Alzheimer's disease. J Clin Psychiatry 57 Suppl 14:9-13

22. Drzezga A, Lautenschlager N, Siebner H, Riemenschneider M, Willoch F, Minoshima S, Schwaiger M, Kurz A (2003) Cerebral metabolic changes accompanying conversion of mild cognitive impairment into Alzheimer's disease: a PET follow-up study. Eur J Nucl Med Mol Imaging 30:1104-1113

23. Mosconi L, Nacmias B, Sorbi S, De Cristofaro MT, Fayazz M, Tedde A, Bracco L, Herholz K, Pupi A (2004) Brain metabolic decreases related to the dose of the ApoE e4 allele in Alzheimer's disease. J Neurol Neurosurg Psychiatry 75:370-376

24. Reiman EM, Chen K, Alexander GE, Caselli RJ, Bandy D, Osborne D, Saunders AM, Hardy J (2004) Functional brain abnormalities in young adults at genetic risk for late-onset Alzheimer's dementia. Proc Natl Acad Sci USA 101:284-289

25. Perry G, Smith MA, McCann CE, Siedlak SL, Jones PK, Friedland RP (1998) Cerebrovascular muscle atrophy is a feature of Alzheimer's disease. Brain Res 791:63-66

26. Kalaria RN, Gravina SA, Schmidley JW, Perry G, Harik SI (1988) The glucose transporter of the human brain and blood-brain barrier. Ann Neurol 24:757-764

27. Jagust W, Gitcho A, Sun F, Kuczynski B, Mungas D, Haan M (2006) Brain imaging evidence of preclinical Alzheimer's disease in normal aging. Ann Neurol 59:673-681

28. Martins RN (2001) Amyloid beta protein precursor metabolism as a modulator of islet beta-cell function. J Alzheimers Dis 3:397-399

29. Lester-Coll N, Rivera EJ, Soscia SJ, Doiron K, Wands JR, de la Monte SM (2006) Intracerebral streptozotocin model of type 3 diabetes: relevance to sporadic Alzheimer's disease. J Alzheimers Dis 9:13-33

30. Rivera EJ, Goldin A, Fulmer N, Tavares R, Wands JR, de la Monte SM (2005) Insulin and insulin-like growth factor expression and function deteriorate with progression of Alzheimer's disease: link to brain reductions in acetylcholine. J Alzheimers Dis 8:247-268

31. Steen E, Terry BM, Rivera EJ, Cannon JL, Neely TR, Tavares R, Xu XJ, Wands JR, de la Monte SM (2005) Impaired insulin and insulin-like growth factor expression and signaling mechanisms in Alzheimer's disease-is this type 3 diabetes? J Alzheimers Dis 7:63-80 
32. de la Monte SM, Wands JR (2005) Review of insulin and insulin-like growth factor expression, signaling, and malfunction in the central nervous system: relevance to Alzheimer's disease. J Alzheimers Dis 7:45-61

33. Hoppener JW, Ahren B, Lips CJ (2000) Islet amyloid and type 2 diabetes mellitus. N Engl J Med 343:411-419

34. Hoyer S (1998) Risk factors for Alzheimer's disease during aging. Impacts of glucose/energy metabolism. J Neural Transm Suppl 54:187-194

35. Perry G, Nunomura A, Raina AK, Aliev G, Siedlak SL, Harris PL, Casadesus G, Petersen RB, Bligh-Glover W, Balraj E, Petot GJ, Smith MA (2003) A metabolic basis for Alzheimer disease. Neurochem Res 28:1549-1552

36. Smith MA, Petot GJ, Perry G (1999) Diet and oxidative stress: a novel synthesis of epidemiological data on Alzheimer's disease. J Alzheimers Dis 1:203-206

37. Grant WB (1999) Dietary links to Alzheimer's disease: 1999 update. J Alzheimers Dis 1:197-201

38. Saunders AM, Schmader K, Breitner JC, Benson MD, Brown WT, Goldfarb L, Goldgaber D, Manwaring MG, Szymanski MH, McCown N et al (1993) Apolipoprotein E epsilon 4 allele distributions in late-onset Alzheimer's disease and in other amyloid-forming diseases. Lancet 342:710711

39. Petot GJ, Friedland RP (2004) Lipids, diet and Alzheimer disease: an extended summary. J Neurol Sci 226:31-33

40. Grant WB (2004) Obesity and Alzheimer disease: roles of diet and genetics. Arch Intern Med 164:109-110, author reply 110

41. Farris W, Mansourian S, Leissring MA, Eckman EA, Bertram L, Eckman CB, Tanzi RE, Selkoe DJ (2004) Partial loss-of-function mutations in insulin-degrading enzyme that induce diabetes also impair degradation of amyloid betaprotein. Am J Pathol 164:1425-1434

42. Craft S, Asthana S, Cook DG, Baker LD, Cherrier M, Purganan K, Wait C, Petrova A, Latendresse S, Watson GS, Newcomer JW, Schellenberg GD, Krohn AJ (2003) Insulin dose-response effects on memory and plasma amyloid precursor protein in Alzheimer's disease: interactions with apolipoprotein E genotype. Psychoneuroendocrinology 28:809-822

43. Zhao L, Teter B, Morihara T, Lim GP, Ambegaokar SS, Ubeda OJ, Frautschy SA, Cole GM (2004) Insulin-degrading enzyme as a downstream target of insulin receptor signaling cascade: implications for Alzheimer's disease intervention. J Neurosci 24:11120-11126

44. Odetti P, Angelini G, Dapino D, Zaccheo D, Garibaldi S, Dagna-Bricarelli F, Piombo G, Perry G, Smith M, Traverso N, Tabaton M (1998) Early glycoxidation damage in brains from Down's syndrome. Biochem Biophys Res Commun 243:849-851

45. Cash AD, Aliev G, Siedlak SL, Nunomura A, Fujioka H, Zhu X, Raina AK, Vinters HV, Tabaton M, Johnson AB,
Paula-Barbosa M, Avila J, Jones PK, Castellani RJ, Smith MA, Perry G (2003) Microtubule reduction in Alzheimer's disease and aging is independent of tau filament formation. Am J Pathol 162:1623-1627

46. Dubelaar EJ, Mufson EJ, ter Meulen WG, Van Heerikhuize JJ, Verwer RW, Swaab DF (2006) Increased metabolic activity in nucleus basalis of Meynert neurons in elderly individuals with mild cognitive impairment as indicated by the size of the Golgi apparatus. J Neuropathol Exp Neurol 65:257-266

47. Munoz DG, Feldman H (2000) Causes of Alzheimer's disease. CMAJ 162:65-72

48. Khachaturian AS, Corcoran CD, Mayer LS, Zandi PP, Breitner JC (2004) Apolipoprotein E epsilon4 count affects age at onset of Alzheimer disease, but not lifetime susceptibility: the Cache county study. Arch Gen Psychiatry 61:518-524

49. Miyata M, Smith JD (1996) Apolipoprotein E allele-specific antioxidant activity and effects on cytotoxicity by oxidative insults and beta-amyloid peptides. Nat Genet 14:55-61

50. Strittmatter WJ, Saunders AM, Goedert M, Weisgraber KH, Dong LM, Jakes R, Huang DY, Pericak-Vance M, Schmechel D, Roses AD (1994) Isoform-specific interactions of apolipoprotein $\mathrm{E}$ with microtubule-associated protein tau: implications for Alzheimer disease. Proc Natl Acad Sci USA 91:11183-11186

51. Harwood DG, Barker WW, Ownby RL, Mullan M, Duara R (2002) Apolipoprotein E polymorphism and cognitive impairment in a bi-ethnic community-dwelling elderly sample. Alzheimer Dis Assoc Disord 16:8-14

52. Bellivier F, Laplanche JL, Schurhoff F, Feingold J, Feline A, Jouvent R, Launay JM, Leboyer M (1997) Apolipoprotein E gene polymorphism in early and late onset bipolar patients. Neurosci Lett 233:45-48

53. Schmand B, Hooijer C, Jonker C, Lindeboom J, Havekes LM (1998) Apolipoprotein E phenotype is not related to late-life depression in a population-based sample. Soc Psychiatry Psychiatr Epidemiol 33:21-26

54. Howard BV, Gidding SS, Liu K (1998) Association of apolipoprotein $\mathrm{E}$ phenotype with plasma lipoproteins in African-American and white young adults. The CARDIA Study. Coronary Artery Risk Development in Young Adults. Am J Epidemiol 148:859-868

55. Igata-Yi R, Igata $\mathrm{T}$, Ishizuka K, Kimura $\mathrm{T}$, Sakamoto $\mathrm{S}$, Katsuragi S, Takamatsu J, Miyakawa T (1997) Apolipoprotein E genotype and psychosis. Biol Psychiatry 41:906-908

56. Lehtimaki T, Moilanen T, Porkka K, Akerblom HK, Ronnemaa T, Rasanen L, Viikari J, Ehnholm C, Nikkari T (1995) Association between serum lipids and apolipoprotein $\mathrm{E}$ phenotype is influenced by diet in a population-based sample of free-living children and young adults: the Cardiovascular Risk in Young Finns Study. J Lipid Res 36:653-661 